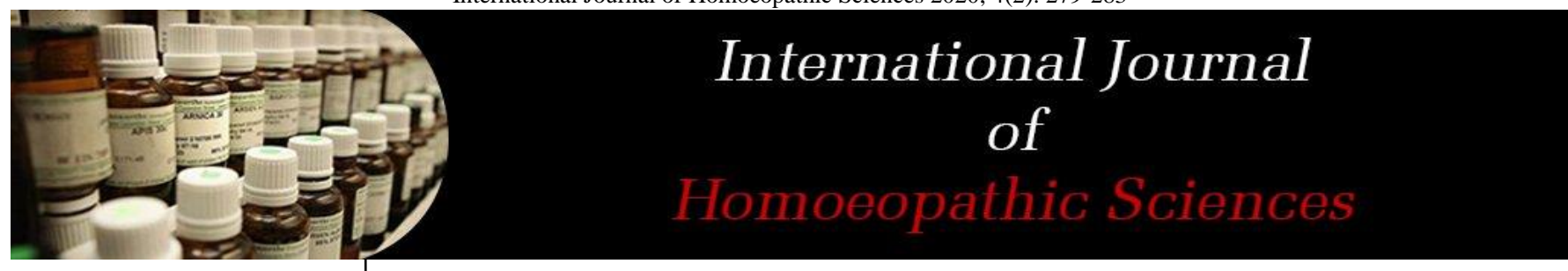

E-ISSN: $2616-4493$

P-ISSN: 2616-4485

www.homoeopathicjournal.com

IJHS 2020; 4(2): 279-283

Received: 17-02-2020

Accepted: 21-03-2020

Ana Catarina Viana Valle

1. Graduate Program in

Genomic Sciences and

Biotechnology, Catholic

University of Brasilia, Postal

Code, Brasília, DF, Brazil

2. IDIS Lamasson, Doctor Izao

Soares Institute, Postal

Code, São Paulo, SP, Brazil

Lana Ribeiro Aguiar

BioInnova Laboratory, Postal

Code, Brasília, DF, Brazil

Hilana Dos Santos Sena Brune BioInnova Laboratory, Postal Code, Brasília, DF, Brazil

Patricia Furtado Malard BioInnova Laboratory, Postal Code, Brasília, DF, Brazil

Rosângela Vieira De Andrade Graduate Program in Genomic Sciences and Biotechnology, Catholic University of Brasilia, Postal Code, Brasília, DF, Brazil

Corresponding Author: Hilana Dos Santos Sena Brunel BioInnova Laboratory, Postal Code, Brasília, DF, Brazil

\section{Analysis of the performance of the ultra-diluted Viscum album in cultivation of mesenchymal stem cells and mammary adenocarcinoma cells pmc-42 and mef-7}

\author{
Ana Catarina Viana Valle, Lana Ribeiro Aguiar, Hilana Dos Santos \\ Sena Brunel, Patricia Furtado Malard and Rosângela Vieira De \\ Andrade
}

DOI: https://doi.org/10.33545/26164485.2020.v4.i2d.179

\begin{abstract}
Adenocarcinoma in breast can be of several types and PMC-42 and MCF-7 cell lines are a wellestablished cell lines used in in vitro studies retaining much of the breast's native phenotype. Viscum album, a plant which extract has cytotoxic effects, is included in the brand-new class of cancer therapies and its ultra-diluted version is a promising area of interest. The MTT assay was realized to evaluate the cytotoxic potential and calculate the inhibitory concentration of different concentrations of ultra-diluted Viscum album D30 (VAD30). The results indicated that $60 \mu \mathrm{L} / \mathrm{mL}, 37 \mu \mathrm{L} / \mathrm{mL}$ and $35 \mu \mathrm{l} / \mathrm{mL}$ of VAD30 were cytotoxic to 50\% of mesenchymal stem cell, MCF-7 and PMC-42 cells respectively. This result shows the better potency of action of VAD30 against tumor cells, as a lower concentration inhibits the growing of this cell line in comparison to health cells, demonstrating that this medicine has the potential to be used in cancer therapy.
\end{abstract}

Keywords: Viscum album, homeopathy, cell viability, tumor cells

\section{Introduction}

Several in vitro methods using cell cultures have been standardized for the evaluation and/or prediction of toxicity, as well as for predictive evaluation of substance efficacy, and have favored the refinement, reduction or replacement of tests using animals in experimentation [1]. Aiming to achieve the basic principles of the 3Rs: Replacement, Reduction and Refinement; proposed since 1959 by Russell and Burch ${ }^{[2]}$ and reviewed extensively by Kandárová et al. ${ }^{[3,4]}$, where significant progress has been made using the screening procedure, through the integration of in vitro tests by cell cultures and computer systems (in silico) to reduce or even replace the use of animals ${ }^{[5]}$. Thus, modern study guides (guidelines) have been proposed for the use of alternative methods in the process of basic and applied research of substances with the purpose of replacing, refining or reducing the use of animals ${ }^{[6]}$.

Among the therapies that have been gaining space in the routine of the integrative clinic are homeopathic medicine, which are routinely used, however, in vitro studies involving them are rare, which promotes persistence in relation to concerns regarding their experimental validation. and mechanism of action ${ }^{[7,8]}$. Therefore, with the possibility of evaluations that can be performed today, ultra-diluted medicine can show efficacy and safety in in vitro culture conditions, being possible to evaluate the possible variation of their action according to the dilution [7]. Homeopathic medicine has been used for centuries as a medical alternative, highlighting the use of Viscum album in integrative oncology therapy [9-11]. However, safety trials to validate the efficacy and reproducibility of the actions of ultradiluted medicine are necessary ${ }^{[12,13]}$.

The toxicology field has been challenged by the exponential discovery of new substances. Public pressure for not using animals in research and experimentation and the need to develop new methodologies that involve different toxicological outcomes for safety assessment, as well as the validation of these methods it is becoming more and more necessary ${ }^{[14]}$. This is also because animal toxicity tests are not always applicable to human health due to interspecies variations. Therefore, alternative methods to the use of animals have been considered efficient alternatives, either with the use of the species-specific cell or tissue platform or even in chemico or in silico assessments to predict toxicity ${ }^{[15-20]}$. 
In vitro product safety assessment studies involve cytotoxicity analysis, in which the main cell models used are primary cell cultures and strains, sometimes immortalized ${ }^{[21,22]}$. Thus, an immense range of cell types can be studied in relation to cytotoxicity, and a cell type with high potential for these assessments is the mesenchymal stem cell (MSC), due to its capacity for selfrenewal and differentiation potential ${ }^{[23]}$.

Previous studies have evaluated bone marrow MSCs as a good model for predicting toxicological class by the neutral red uptake assay when comparing with already validated $3 \mathrm{~T} 3 \mathrm{NHKs}$ and murine fibroblasts cells where 12 chemical reference reagents were tested for this validation ${ }^{[24]}$. These results are promising, however stem cells derived from bone marrow are difficult to obtain, which made it interesting to evaluate this same potential of mesenchymal stem cells obtained from adipose tissue (MSC) ${ }^{[23]}$ as they are a group of easy availability, reproducibility and scalability to predict toxicity in in vitro tests ${ }^{[25,26]}$. In this context, Abud and collaborators concluded that MSC represent an interesting cellular model for alternative tests to animal tests with great relevance for the prediction of toxicity that represent an important potential for industrial applications and for regulatory purposes. MSCs can be used to assess the cytotoxicity of chemical compounds, including products that are already established or are still under development ${ }^{[23]}$.

In this study, immortalized adenocarcinoma lineage cells such as PMC-42 and MCF-7 were also evaluated. PMC-42 is a lineage of breast carcinoma established from a pleural effusion of a patient with metastatic breast cancer ${ }^{[27]}$. It is remarkably similar to normal breast epithelial tissue, suggesting that, unlike the most common breast cancer cell lines resulting from luminal or myoepithelial / basal cell tumors, PMC42 is a rarer cell line, originating from a stem cell of the breast, maintaining much of the native breast phenotype ${ }^{[28-31]}$.

MCF-7 is a human breast cancer strain with estrogen, progesterone and glucocorticoid receptors. It is derived from the pleural effusion of a 69-year-old Caucasian metastatic breast cancer (adenocarcinoma), isolated more than 40 years ago, by Dr. Soule, of the Michigan Cancer Foundation, Detroit, Michigan in $1970{ }^{[32,33]}$. MCF-7 cells are useful for in vitro breast studies because they maintained several ideal characteristics specific to the mammary epithelium, such as estrogen processing, in the form of estradiol, through estrogen receptors (ER) in the cell cytoplasm ${ }^{[34,35]}$.

Thus, the objective of the present study was to evaluate the performance of the ultra-diluted Viscum D30 (VAD30) in culturing mesenchymal stem cells derived from human adipose tissue and to compare it with the performance of this medication in culturing PMC-42 breast adenocarcinoma cells and MCF-7.

\section{Material and Methods}

\subsection{Obtaining and cultivating cells}

The mesenchymal stem cells derived from human adipose tissue (MSC) were provided by the BioCell (Cell Therapy Laboratory) and the breast cancer tumor lines PMC-42 and MCF-7 (ATCC® HTB-22 TM) by the Biotechnology and Genomic Sciences laboratory from the Catholic University of Brasilia (purchased by the ATCC and grown according to the protocol). MSCs were grown in Dubellco's Modified Eagle medium (DMEM) and tumor lines in Roswell Park Memorial Institute (RPMI) 1640 medium, both from the
Sigma-Aldrich ${ }^{\circledR}$ brand according to the manufacturers' recommendations.

\subsection{Experimental groups}

To evaluate the cytotoxicity of the ultra-diluted drug VAD30, CTM, PMC-42 and MCF-7 cells were cultured in vitro for 48 hours in the following experimental groups: Control (cells with the respective culture medium) and VAD30 in different concentrations $(10,12.1,14.7,17.8$, $21.5,26.1,31.6,38.3,46.4,56.2,68.1,82.5$ and $100 \mu \mathrm{L}$ per $\mathrm{mL}$ of culture medium). VAD30 ampoules $(1.1 \mathrm{~mL})$ were obtained from the company Injectcenter ${ }^{\circledR}$ (Ribeirão Preto, Brazil), which produced the drug according to the German and French pharmacopoeias.

\subsection{Cell viability assay (MTT and $\mathrm{IC}_{50}$ )}

The cytotoxicity of the drug was determined in the respective cell lines by means of a colorimetric assay that measures the reduction of $\{[3-(4,5$-dimethylthiazol-2yl) 2,5-diphenyl tetrazolium]\} (MTT) by mitochondrial activity. For this cell viability assay, cells were initially cultured in triplicate in 96-well plates containing $1 \times 10^{4}$ cells $/ \mathrm{mL}$ of the respective culture medium under an incubator at $37.5^{\circ} \mathrm{C}, 5 \% \mathrm{CO}_{2}$ for 24 hours for stabilization and cell adhesion. After this period, the in vitro culture medium was replaced and the evaluation factor containing the VAD30 in different concentrations (10 to $100 \mu \mathrm{L} / \mathrm{mL}$ ) was added to each group and the cells were cultured for another 48 hours. After this period, the culture medium was removed and $100 \mu \mathrm{L}$ of the solution containing 3- (4,5dimethylthiazol-2-yl) -2,5-diphenyl tetrazolium bromide (Catalog: Sigma N. M2128) at $0.5 \mathrm{mg} / \mathrm{mL}$ was added to each well and incubated for 4 hours at $37.5{ }^{\circ} \mathrm{C}$ and $5 \% \mathrm{CO}_{2}$ protected from light. Then, the supernatant was removed and $100 \mu \mathrm{L}$ of DMSO was added to each well, homogenized and evaluated in a microplate spectrophotometer for capturing absorbance in the 570nm spectrum (Molecular Devices, Sunnyvale, CA, USA) to identify viable cell density. Finally, after obtaining the data, the inhibitory concentration for $50 \%$ of the cells $\left(\mathrm{IC}_{50}\right)$ of each cell type was calculated, that is, the response concentration by which cell viability is reduced to $50 \%$.

\subsection{Statistical analysis}

The analysis of the results of the MTT tests were performed in the Graph Prism 7.04 program by the Tukey test for multiple comparisons. Where $(*)$ : $\mathrm{P}$ value $\leq 0.05 ;(* *)$ : $\mathrm{P}$ value $\leq 0.01 ;(* * *): \mathrm{P}$ value $\leq 0.001 ;$ and $(* * * *)$ : $\mathrm{P}$ value $\leq$ 0.0001 .

\section{Results and Discusion}

Firstly, the impact of VAD30 concentrations on the viability of MSC cells was analyzed after 48 hours of in vitro culture (Figure 1), MSC were subjected to in vitro culture medium with the addition of VAD30 in the different concentrations tested $(10 \mu \mathrm{L} / \mathrm{mL}-100 \mu \mathrm{L} / \mathrm{mL})$ and for the control group were grown without the addition of VAD30. The mean absorbance variation measured were significant in relation to the control sample that had no contact with the homeopathic, mainly from the tested concentration of 26.1 $\mu \mathrm{L} / \mathrm{mL}$ where a $\mathrm{p}$ Value $\leq 0.0001$ is observed. The results (Table 1) demonstrated a maintenance of the quantity of cells after in vitro culture for 48 hours at the lowest concentrations tested, with a decrease in the observed 
maintenance (less than $75 \%$ ) from the concentration of 46.4 $\mu \mathrm{L} / \mathrm{mL}$ (p Value of 0.0001).

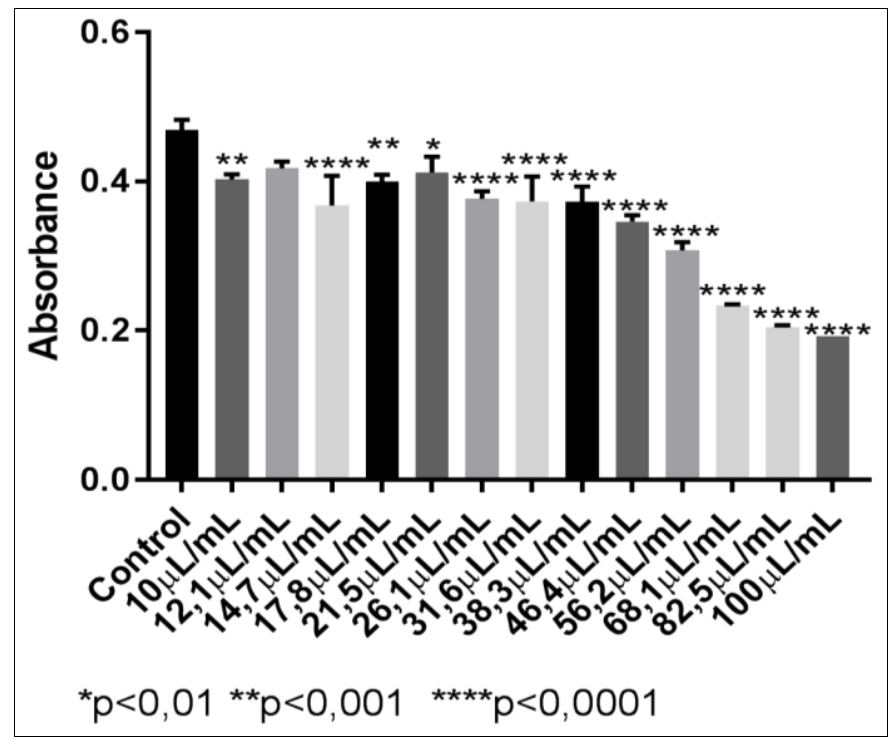

Fig 1: Absorbance measured in the cell viability assay of MSCs with ultra-diluted VAD30 at the different concentrations investigated (10 to $100 \mu \mathrm{L} / \mathrm{mL}$ ) after $48 \mathrm{~h}$ of culture

For the tumor cells PMC-42 (Figure 2) and MCF-7 (Figure 3 ) it can be seen that, the action of VAD30 was more effective considering that it was possible to observe that a greater efficiency of cell death occurred with the tumor cells. Separately, the PMC-42 cells showed a large variation in absorbance when comparing the samples with the homeopathic compared to the control sample, with significant action being observed at low concentrations.

The results demonstrated a reduction in the cell quantity after in vitro culture for 48 hours at the lowest concentrations tested, with a more significant decrease observed from the concentration of $21.5 \mu \mathrm{L} / \mathrm{mL}$.

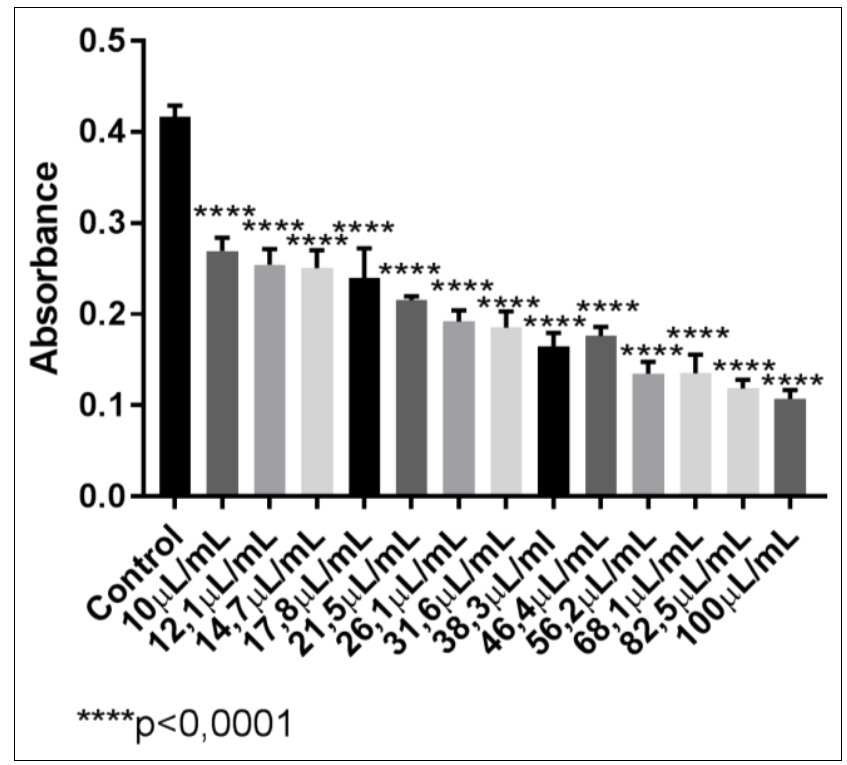

Fig 2: Percentage of cell viability after 72 hours of cultivation of PMC-42 cells with VAD30 at different concentrations.

As with the PMC-42 cells, the MCF-7 cells (Figure 3), also showed a large variation in absorbance when compared to the control sample. The results demonstrated a reduction in the cell quantity after in vitro culture for 48 hours at the lowest concentrations tested, with a more significant decrease observed from the concentration of $21.5 \mu \mathrm{L} / \mathrm{mL}$.

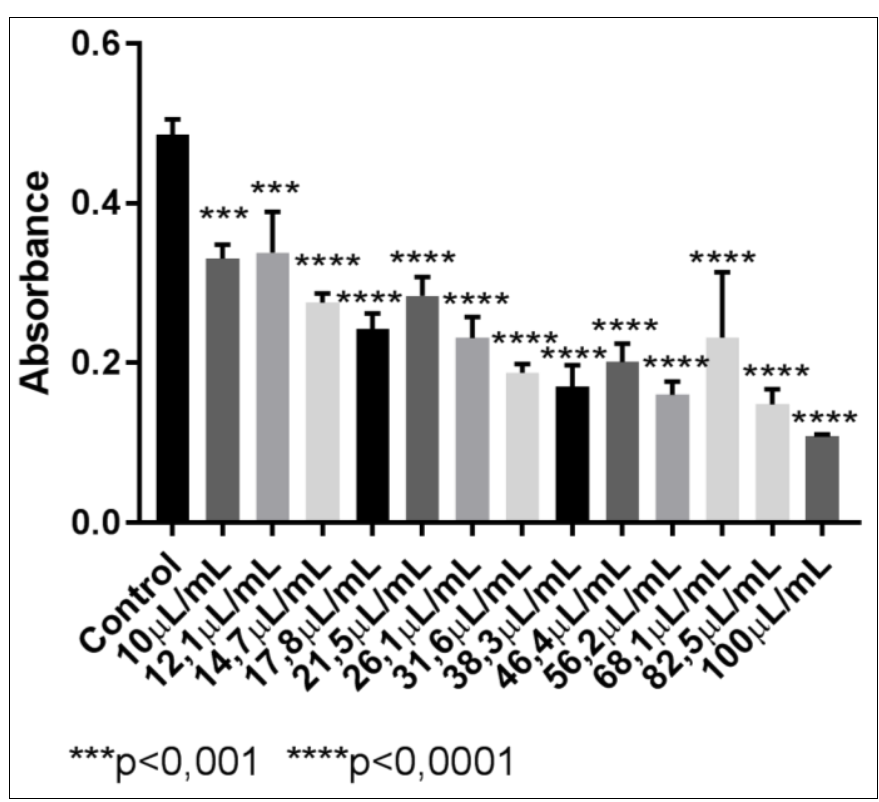

Fig 3: Percentage of cell viability after 72 hours of cultivation of MCF-7 cells with VAD30 at different concentrations.

The cell viability values obtained in each assay by the MTT test and the cytotoxicity value by concentration-response $\left(\mathrm{IC}_{50}\right)$ are described in Table 1.

It can be observed that VAD30 has a cytotoxic action for the tumor cells of PMC-42 and MCF-7 with $\mathrm{IC}_{50}$ of 35.81 and 37.5 respectively, as well as a cytotoxic action can be observed with the MSC cells, with less intensity than that observed in tumor cells ( $\mathrm{IC}_{50}$ : 79.77). Corroborating what the results obtained by evaluating the absorbance index.

Table 1: Cell viability at test concentrations. Descriptive data with the values obtained from cell viability by MTT and the value of cytotoxicity by concentration-response (IC50) for each cell type with VAD30 and control test.

\begin{tabular}{|c|c|c|c|}
\hline $\begin{array}{c}\text { Concentration of } \\
\text { VA30 }(\boldsymbol{\mu L} \mathbf{L L})\end{array}$ & $\begin{array}{c}\text { \% viability } \\
\text { MSC }\end{array}$ & $\begin{array}{c}\text { \% viability } \\
\text { PMC-42 }\end{array}$ & $\begin{array}{c}\text { \% viability } \\
\text { MCF-7 }\end{array}$ \\
\hline 0 & 100 & 100 & 100 \\
\hline 10 & 85,86 & 64,69 & 68,15 \\
\hline 12,1 & 89,06 & 61,09 & 69,66 \\
\hline 14,7 & 78,33 & 60,21 & 56,76 \\
\hline 17,8 & 85,15 & 57,65 & 50,03 \\
\hline 21,5 & 87,85 & 51,80 & 58,54 \\
\hline 26,1 & 80,32 & 46,12 & 47,63 \\
\hline 31,6 & 79,54 & 44,44 & 38,71 \\
\hline 38,3 & 79,40 & 39,47 & 35,21 \\
\hline 46,4 & 73,79 & 42,27 & 41,46 \\
\hline 56,2 & 65,62 & 32,35 & 33,01 \\
\hline 68,1 & 49,78 & 32,43 & 47,77 \\
\hline 82,5 & 43,53 & 28,42 & 30,54 \\
\hline 100 & 41,12 & 25,78 & 22,37 \\
\hline $\mathrm{IC}_{50}$ & 79,77 & 35,81 & 37,5 \\
\hline & & & \\
\hline
\end{tabular}

As shown in Figure 1-3 and Table 1, it is highlighted that the use of VAD30 regardless of the concentration used, the presence of the ultra-diluted Viscum album in the in vitro culture medium has deleterious effects on cell viability, in smaller proportions when using low concentrations. This data corroborates the result described in the meta-analysis 
carried out by Bonamin et. al. (2017) why they showed that the Viscum album has a cytotoxic action against cancer cells, creating a suitable environment for a new understanding of science ${ }^{[9,10]}$, this result being obtained with VAD30 already considered a safety test of the ultradiluted medicine, as indicated by Cesar ${ }^{[12]}$. However, other safety tests and clinical tests are still needed to assess the side effects that involve the action of this ultra-diluted medicine ${ }^{[36]}$.

This type of tests is important to evaluate the pattern of actions of determinate medicine, bearing in mind that some extracts present a pattern that is not dependent on concentration, like in the case of Ruta graveolens extract, where the same antitumor activity was found, but when the higher concentration was used, the cytotoxic activity was found to be reduced than that of the lower concentration ${ }^{[37]}$. The methodology used in this work complies with the new rules for reducing the use of animals in research and experimentation ${ }^{[14]}$, being already used for a previous screening of the evaluation of safety and cytotoxicity, as well as the validation of these methods. The fact that it is carried out in human cell culture is a great advance, since animal toxicity tests are not always applicable to human health due to interspecies variations ${ }^{[15-18]}$.

\section{Conclusion}

In this work it was demonstrated that VAD30 in different concentrations has cytotoxic action in healthy cells (MSC) only in high concentrations. Its greatest cytotoxicity was observed in tumor cells, with low concentrations in breast cancer cells (PMC-42 and MCF-7), making part of these cells unfeasible in vitro. This is a promising and relevant result because it shows the inhibitory potential of VAD30 in breast cancer cells. In addition, this result is relevant because it opens up new avenues to be explored also in vivo. The use of this medication in homeopathic form brings new possibilities for the treatment of breast cancer with no or less adverse effects present, which would be extremely important for the quality of life of patients.

\section{Acknowledgements}

The authors thank João Henrique Viana for the support with statistical analysis. The authors thank company Injectcenter ${ }^{\circledR}$ for supplying the ampoules of Viscum album D30.

\section{References}

1. Andersen ME, Krewski D. Toxicity testing in the 21st century: Bringing the vision to life. Toxicol Sci 2009; 107:324-30. https://doi.org/10.1093/toxsci/kfn255.

2. Russell WMS, Burch R. The Principles of Humane Experimental Technique. Methuen \& CO LTD, 1959.

3. Kirk RGW. Recovering the Principles of Humane Experimental Technique: The 3Rs and the Human Essence of Animal Research. Sci Technol Hum Values. 2018; 43:622-48. https://doi.org/10.1177/0162243917726579.

4. Kandárová $\mathrm{H}$, Letaáiová $\mathrm{S}$. Alternative methods in toxicology: Pre-validated and validated methods. Interdiscip Toxicol 2011; 4:107-13. https://doi.org/10.2478/v10102-011-0018-6.

5. Ahuja V, Sharma S. Drug safety testing paradigm, current progress and future challenges: an overview. J Appl Toxicol. 2014; 34:576-94. https://doi.org/10.1002/jat.2935.

6. Chew EY. The value of randomized clinical trials in ophthalmology. Am J Ophthalmol. 2011; 151:575-8. https://doi.org/10.1016/j.ajo.2010.12.006.

7. Samadder A, Das S, Das J, Paul A, Boujedaini N, Khuda-Bukhsh AR. The potentized homeopathic drug, Lycopodium clavatum (5C and 15C) has anti-cancer effect on HeLa cells in vitro. JAMS J Acupunct Meridian Stud 2013; 6:180-7. https://doi.org/10.1016/j.jams.2013.04.004.

8. Matthes H, Thronicke A, Hofheinz R-D, Baars E, Martin D, Huber R et al. Statement to an Insufficient Systematic Review on Viscum album L. Therapy. Evid Based Complement Alternat Med. 2020; 2020:7091039. https://doi.org/10.1155/2020/7091039.

9. Bonamin LV, Lagache A, Bastide M. Research on Ultra-dilutions and the Theory of Corporeal Signifiers: The Follow Up. Signals and Images, Springer Netherlands, 2008, 3-25. https://doi.org/10.1007/978-14020-8535-2_1.

10. Bonamin LV, De Carvalho AC, Waisse S. Viscum album (L.) in experimental animal tumors: A metaanalysis. Exp Ther Med 2017; 13:2723-40. https://doi.org/10.3892/etm.2017.4372.

11. Downer SM, Cody MM, McCluskey P, Wilson PD, Arnott SJ, Lister TA et al. Pursuit and practice ofcomplementary therapies by cancer patients receiving conventional treatment. BMJ. 1994; 309:86-9.

12. Cesar B, Abud APR, de Oliveira CC, Cardoso F, Gremski W, Gabardo J et al. Activation of mononuclear bone marrow cells treated in vitro with a complex homeopathic medication. Micron. 2008; 39:461-70. https://doi.org/10.1016/j.micron.2007.02.005.

13. Steinborn C, Klemd AM, Sanchez-Campillo AS, Rieger S, Scheffen M, Sauer B et al. Viscum album neutralizes tumor-induced immunosuppression in a human in vitro cell model. PLoS One. 2017; 12:e0181553. https://doi.org/10.1371/journal.pone.0181553.

14. Jennings $P$. The future of in vitro toxicology. Toxicol Vitr. 2015; 29:1217-21. https://doi.org/10.1016/j.tiv.2014.08.011.

15. Liebsch M, Grune B, Seiler A, Butzke D, Oelgeschläger M, Pirow R et al. Alternatives to animal testing: Current status and future perspectives. Arch Toxicol. 2011; 85:841-58. https://doi.org/10.1007/s00204-011-0718-x.

16. Eskes C, van Vliet E, Maibach HI. Alternatives for dermal toxicity testing. Springer International Publishing. 2017. https://doi.org/10.1007/978-3-31950353-0.

17. Piersma AH. General rights Workshop on acceleration of the validation and regulatory acceptance of alternative methods and implementation of testing strategies, 2018. https://doi.org/10.1016/j.tiv.2018.02.018.

18. Pamies D, Bal-Price A, Simeonov A, Tagle D, Allen D, Gerhold D et al. Good cell culture practice for stem cells \& stem-cell-derived models. ALTEX, vol. 34, Elsevier GmbH; 2017, 95-132. https://doi.org/10.14573/altex.1607121.

19. Pamies D, Hartung T. 21 st century cell culture for $21 \mathrm{st}$ century toxicology. Chem Res Toxicol. 2017; 30:4352. https://doi.org/10.1021/acs.chemrestox.6b00269.

20. Rodriguez B. The 18th FRAME Annual Lecture, 2019: 
Human in Silico Trials in Pharmacology. Altern Lab Anim 2019; 47:221-7. https://doi.org/10.1177/0261192919896356.

21. Kleensang A, Vantangoli MM, Odwin-Dacosta S, Andersen $\mathrm{ME}$, Boekelheide $\mathrm{K}$, Bouhifd $\mathrm{M}$, et al. Genetic variability in a frozen batch of MCF-7 cells invisible in routine authentication affecting cell function. Sci Rep. 2016; 6:1-11. https://doi.org/10.1038/srep28994.

22. Niu C, Jin $\mathrm{H}, \mathrm{Li} \mathrm{M}, \mathrm{Xu} \mathrm{J}, \mathrm{Xu} \mathrm{D}, \mathrm{Hu} \mathrm{J}$ et al. In vitro analysis of the proliferative capacity and cytotoxic effects of ex vivo induced natural killer cells, cytokineinduced killer cells, and gamma-delta $\mathrm{T}$ cells. BMC Immunol. 2015; 16:61. https://doi.org/10.1186/s12865015-0124-X.

23. Abud APR, Zych J, Reus TL, Kuligovski C, de Moraes $\mathrm{E}$, Dallagiovanna B et al. The use of human adiposederived stem cells based cytotoxicity assay for acute toxicity test. Regul Toxicol Pharmacol. 2015; 73:9928. https://doi.org/10.1016/j.yrtph.2015.09.015.

24. Scanu M, Mancuso L, Cao G. Evaluation of the use of human Mesenchymal Stem Cells for acute toxicity tests. Toxicol Vitro. 2011; 25:1989-95. https://doi.org/10.1016/j.tiv.2011.07.006.

25. Hook LA. Stem cell technology for drug discovery and development. Drug Discov Today 2012; 17:336-42. https://doi.org/10.1016/j.drudis.2011.11.001.

26. Kang KS, Trosko JE. Stem Cells in Toxicology: Fundamental Biology and Practical Considerations. Toxicol Sci. 2011; 120:269-89. https://doi.org/10.1093/toxsci/kfq370.

27. Git A, Spiteri I, Blenkiron C, Dunning MJ, Pole JCM, Chin SF et al. PMC42, a breast progenitor cancer cell line, has normal-like mRNA and microRNA transcriptomes. Breast Cancer Res. 2008; 10:R54. https://doi.org/10.1186/bcr2109.

28. Whitehead RH, Monaghan P, Webber LM, Bertoncello I, Vitali AA. A new human breast carcinoma cell line (PMC42) with stem cell characteristics. II. Characterization of cells growing as organoids. J Natl Cancer Inst. 1983; 71:1193-203.

29. Whitehead RH, Quirk SJ, Vitali AA, Funder JW, Sutherland RL, Murphy LC. A new human breast carcinoma cell line (PMC42) with stem cell characteristics. III. Hormone receptor status and responsiveness. J Natl Cancer Inst. 1984; 73:643-8.

30. Whitehead RH, Bertoncello I, Webber LM, Pedersen JS. A new human breast carcinoma cell line (PMC42) with stem cell characteristics. I. Morphologic characterization. J Natl Cancer Inst. 1983; 70:649-61.

31. Ackland ML, Michalczyk A, Whitehead RH. PMC42, a novel model for the differentiated human breast. Exp Cell Res 2001; 263:14-22. https://doi.org/10.1006/excr.2000.5106.

32. Camarillo IG, Xiao F, Madhivanan S, Salameh T, Nichols M, Reece LM et al. Low and high voltage electrochemotherapy for breast cancer: an in vitro model study. Electroporation-Based Ther. Cancer, Elsevier; 2014, 55-102. https://doi.org/10.1533/9781908818294.55.

33. Levenson AS, Jordan VC. MCF-7: The first hormoneresponsive breast cancer cell line. Cancer Res. 1997; 57:3071-8.

34. Osborne CK, Hobbs K, Trent JM. Biological differences among MCF-7 human breast cancer cell lines from different laboratories. Breast Cancer Res Treat 1987; 9:111-21. https://doi.org/10.1007/bf01807363.

35. Comşa Ş, Cîmpean AM, Raica M. The Story of MCF-7 Breast Cancer Cell Line: 40 years of Experience in Research. Int J Cancer Res Treat 2015; 3154:3147-54. https://doi.org/10.1038/430021a.

36. OECD. Oecd/Ocde 487 Oecd Guideline for The Testing of Chemicals - In Vitro Mammalian Cell Micronucleus Test. 2016.

37. Preethi KC, Kuttan G, Kuttan R. Anti-Tumour activity of Ruta Graveolens extract. Asian Pacific J Cancer Prev. 2006; 7:439-43. 